\title{
THE NATURE OF PROVINCIAL MEDICAL PRACTICE IN EIGHTEENTH-CENTURY ENGLAND
}

\author{
by
}

IRVINE LOUDON*

I

When one looks at the history of the medical profession in eighteenth-century England, the striking feature is the extent to which historians have concentrated on the minority of famous and distinguished medical men, mostly in London, and how little is known of the much more numerous rank-and-file practitioners of provincial England. This paper is part of a study that attempts to redress the balance by an examination of the clinical practice, the social status, and the economic rewards of ordinary provincial medical men.

The reason for their neglect is partly the obvious one that the famous tend to leave copious records, the obscure very few and those few that survive are usually scattered and incomplete. It is, nevertheless, possible, on the basis of such records as exist, to offer and test certain hypotheses; for example, that the surgeon-apothecary of the eighteenth century was first and foremost a businessman, and often a very successful one, motivated by a hard sense of commercialism; and that the divisions of medical men suggested by the variety of titles and designations found in the eighteenth century meant very little because the type of practice adopted by an individual was dictated most of all by the competition and opportunities for business in his chosen area of practice. It will also be suggested that eighteenth-century medical practitioners were employed on a large scale not just for the treatment of serious life-threatening illness, but for minor self-limiting conditions; and that they were employed in this way not solely by an upper class well able to pay for medical care, but by a wide range of social classes. Surgery, in particular, has been too often portrayed as an agonizing business of "heroic" and desperate capital operations; here it will be shown that such operations were rare events, and over ninety-five per cent of country surgical practice consisted of simple, but often effective, procedures. There also seems to be evidence that the first half of the century witnessed a significant rise in the prosperity of ordinary practitioners and that the second half was, in the words of Richard Smith junior, "The Golden Age of Physic".

Most accounts of provincial practice in the eighteenth century suggest that the ordinary practitioners, the apothecaries and surgeon-apothecaries, advanced little if at all in competence or prosperity throughout the century. Such advances in medical knowledge as occurred in British medicine were largely confined to London and

${ }^{*}$ Irvine Loudon, DM, FRCGP, Wellcome Unit for the History of Medicine, 47 Banbury Road, Oxford OX2 6PE. 


\section{Irvine Loudon}

Edinburgh. Here and there in the provinces a few exceptional practitioners stood head and shoulders above the rank and file. John Huxham and William Withering in physic, Charles White and William Hey of Leeds in surgery, and John Ferriar and John Haygarth in hygiene and public health provide a few examples. Most of these pioneers practised in the second half of the century, and most held appointments at hospitals or dispensaries where, through their posts as honorary physicians and surgeons, they were part of a new élite.

Below this level, the rank-and-file provincial practitioners ("the unpretentious apothecaries-the quasi-irregulars") ${ }^{1}$ are often perceived as a group of ill-educated or even near-illiterate tradesmen, who kept shops and combined the sale of medicines with groceries and toilet articles. Their practice was based on a primitive knowledge of physic and pharmacy, surgical operations crudely carried out, and unskilled man-midwifery. The tendency for such men to combine the practice of medicine with another occupation is taken as evidence of the poverty of medical practice at this level. For those who see this as an accurate picture of eighteenth-century provincial practice, it follows that the evolution of such practitioners into prosperous respectable professional men did not occur until the nineteenth century, following the introduction of the Apothecaries' Act of 1815 and the appearance of the general practitioner.

Recently, however, Holmes has put forward a very different thesis. ${ }^{2}$ In his opinion, the medical profession came into existence in the period between 1680 and 1730 because of the rise of the surgeon-apothecary. For the first time, "the doctor truly arrives in English society". 3 His claim is based on the breakdown of the tripartite system-due in part to the Rose case of 1704-and the increasing scope of medical practice signified by the emergence of the surgeon-apothecary; but most of all, perhaps, on the improved education of medical practitioners through attendance at the voluntary hospitals and the private medical schools. ${ }^{4}$ Moreover, Holmes claims that public recognition and the development amongst medical men of a sense of corporate identity played an important part in the "arrival" of the doctor for the people in general. In other words, Holmes sees the transition of medicine from a disparate ill-educated group of practitioners to a "medical profession" as a process that took place in the late seventeenth and early eighteenth centuries, in stark contrast to the more conventional view that these changes took place a century later.

Thus there are many aspects of medicine in the eighteenth century that are still unresolved, and one of the most important is the extent of the market for medical care and how that market was satisfied. One of the key questions here is the relative contribution of the orthodox and the unorthodox practitioners-the regular

${ }^{1}$ R. H. Shryock, The development of modern medicine, Madison, University of Wisconsin Press, 1979, p. 52.

${ }^{2} \mathrm{G}$. Holmes, Augustan England: Professions, state and society, 1680-1730, London, Allen \& Unwin, 1982.

Ibid., p. 167

${ }^{4}$ Holmes's emphasis on advances in medical training forms the weakest part of his thesis. Although there was an increasing tendency for rank-and-file practitioners to attend courses of instruction in hospitals and private medical schools or to go to Edinburgh, very few did so before 1730 . Even by 1750 , it was still a small minority who received such training. There was no substantial improvement in the education of medical practitioners before, at the earliest, the second half of the eighteenth century. 


\section{Provincial medical practice in eighteenth-century England}

practitioners on the one hand and, on the other, the irregulars, empirics, or quacks. It seems obvious at first sight that a large and thriving market for quackery would have tended to depress the general standard of medical care as well as the prosperity of regular practitioners; for we tend to see the situation in adversarial terms with two clearly distinguished and opposing groups of practitioners locked in bitter competition with each other. Any attempt to discover how many patients employed the orthodox medical men, how many the quacks, and how this varied with time and place, raises a number of questions which go beyond a matter of simple rivalry for a single market.

For example, was the market, in social terms, the same for both kinds of practitioner? If so, was there one kind of quack for the rich and another for the poor, or did the same one tailor his approach according to the customer? To what extent were the services of the orthodox and the quack mutually exclusive? Did the public drift from one to the other, or (hedging their bets) utilize both at the same time? In attempting to answer such questions there is the obvious difficulty that quacks rarely left records of their practice. Another, less obvious, but equally serious difficulty, is the frequent impossibility of distinguishing between orthodoxy and heterodoxy in medical practice in the eighteenth century.

Often, it is easy to identify the quacks or empirics because of their remarkable tendency to run true to form. Usually, they were itinerant, advertising their attendance in a certain town for a limited period, and tending to select the same diseases as their particular specialities. With surprising consistency, they claimed to cure some or all of a list of disorders, including eye diseases (especially blindness); ruptures or "broken bellies" (cured by medicines or a special apparatus); cancers (cured without operation); deafness (if the ear-drum was intact); and above all venereal disease, usually mentioned in some coy euphemism. ${ }^{5}$ Often, they entitled themselves "Dr" and sometimes added a medical degree, and they listed the famous or royal patients they claimed to have cured. All this was advertised in characteristic language. ${ }^{6}$ Our knowledge of this group, the blatant or obvious quacks, is based largely on their advertisements; but even here there are pitfalls. "Chevalier" John Taylor (1703-1772, MD Basle 1733, Liège and Cologne 1734), for example, trained at St Thomas's Hospital, London, and was an expert oculist. Yet he was an itinerant practitioner who chose in his advertisements to use in an extreme form the language of the charlatan.

\footnotetext{
${ }^{5}$ For example, the following advertisement appeared in the Sherborne Mercury for Monday, 24 September 1784:

The afflicted who labour under any difficulty disorders or complaints, as well inward as outward, incident to the human body, are hereby acquainted that Doctor and Oculist Goergslenner, from his house No. 34 Queen Square Bristol, is arrived in the City of Exeter, where he intends to stay a considerable time, and from thence shall come to Plymouth. He cures most perfectly all the disorders in the sight and eyes, and likewise those who have lost their hearing and cures with fidelity all the degrees and symptoms of a certain disorder, whether inveterate or recent, or ever so bad, in a short time. Cures most sorts of ruptures (vulgarly called broken bellies) both in young and old people, with a particular medicine, and the most perfect and commodious trusses, made upon his new and much improved construction, without any steel or wood and, so easy to wear that the patient may undergo any fatigue therewith....

${ }^{6}$ For an extensive account of eighteenth-century quackery, to which the author acknowledges his indebtedness, see Roy Porter, 'The language of quackery'; in press (1985), for publication in a volume to be edited by Roy Porter and Peter Burke.
} 


\section{Irvine Loudon}

If we dismiss Taylor as a perverse exception, it still remains true that practitioners in the eighteenth century were to some extent an amorphous group. The blatant quack stood out at one end of the spectrum. At the other, the orthodox practitioner could be identified by one or more of a number of criteria: by the possession of a medical degree if he was a physician; by honorary appointments at a hospital or dispensary; by the orthodoxy of his training, even if it was no more than a standard apprenticeship; and most of all by his methods and style of practice. Between these extremes, a grey area existed where differentiation into neat historical categories is impossible. This should cause no surprise. In the absence of formal training, examination, and licensing, the term "medically qualified" is often meaningless.

These are some of the historical problems that form the background to this paper, which attempts to describe the clinical practice and social and economic status of the provincial medical practitioner of eighteenth-century England.

\section{II}

The evidence presented in this paper is based largely on manuscript sources in provincial record offices. Particular emphasis has been placed on a single ledger which belonged to an eighteenth-century practice in Wells, Somerset. ${ }^{7}$ The importance of this ledger lies in the exceptional quality and quantity of clinical notes which describe the routine of daily practice. Major and minor cases were recorded in unselected sequence. At the time this ledger was used-between 1757 and the early 1760s-two practitioners were in partnership: Benjamin Pulsford, the senior partner, and William Pulsford, his nephew. The cases recorded in the ledger, however, were all those of William.

In the early years of the eighteenth century, this practice was in the hands of Christopher Lucas (c. 1676-1756) ${ }^{8}$ Lucas was both the surgical colleague and friend of Claver Morris (1659-1726), a physician at Wells known chiefly for the edited account of his diary published in $1934 .^{9}$ Christopher Lucas's nephew Benjamin Pulsford (1716-84) was practising in Wells at least as early as $1742,{ }^{10}$ but it is not known whether he was in partnership with his uncle or succeeded him in the practice. In either case, it was probably about 1756 , following the death of Christopher Lucas, that Benjamin Pulsford, in his turn, took into partnership his nephew William Pulsford. The partnership is assumed from the evidence of the ledger. No partnership agreement survives nor evidence of William's apprenticeship or training. William died at the age of twenty-nine in July $1765 .{ }^{11} \mathrm{He}$ was therefore in his early twenties

\footnotetext{
${ }^{7}$ Somerset County Record Office, Taunton. Catologued as the ledger of Benjamin Pulsford (Ref. DD/FS Box 48).

${ }^{8}$ Margaret Allen, 'Medical practice in eighteenth-century Wells', Somerset Historical Studies, 1969, 25-35.

${ }^{9} \mathrm{E}$. Hobhouse (editor), The diary of a West Country physician, London, Simpkin Marshall, 1934.

${ }^{10}$ Based on the evidence of payment of a bill by overseers of the poor.

${ }^{11}$ A commemorative tablet in the cloisters of Wells Cathedral appears to record the date of death as 26 July 1761 . On very close inspection, it can be seen that the stone has been recut and originally the date was recorded as 26 July 1764 . Both dates are incorrect, the true date of death being $26 \mathrm{July} 1765$, recorded in the register of births, deaths, and marriages, and preserved in the library of Wells Cathedral. The probable reason for the mistakes was that the stone was provided long after the death of William Pulsford, by Canon Pulsford of Wells, in the nineteenth century.
} 


\section{Provincial medical practice in eighteenth-century England}

when the entries were made in the ledger, while his uncle and senior partner was in his early forties. The later history of the Pulsfords is only marginally relevant and many details are incomplete. ${ }^{12}$

William Pulsford died without issue; but Benjamin Pulsford had three sons, Lucas, James, and William. Lucas and James became surgeons and Lucas joined his father, living and practising from his father's house. Nothing is known of James except that he died young and apparently without issue. Lucas, who died in 1819 of apoplexy aged sixty-nine, and was described in the Gentleman's Magazine as "for many years an eminent surgeon" in the City of Wells, prospered, and his children rose above the level of the country surgeon: Frances (b. May 1783) married John Tudway, the Member of Parliament for Wells, and Charles Henry Pulsford (1782-1841) became Rector of Burnham and Canon of Wells. The non-medical son of Benjamin, the second William Pulsford in this family, may well have been an ironmonger, ${ }^{13}$ although described in legal documents as "Gent". One of William's five children became an army surgeon, serving as assistant surgeon to the 8th Regiment of Foot and full surgeon to the 1 st Dragoons in the Peninsular war and at Waterloo. He died in 1819 in Manchester (the same year as his uncle and namesake, Lucas) and, as far as is known, was the last of this dynasty.

Only one ledger has survived from the records of this practice, but it is clear that several were used simultaneously. In this ledger each entry began with the name of an individual or the head of a family. When an address was added, it was always somewhere outside the city of Wells, suggesting that the non-entry of an address indicated a patient living in Wells. In about one-third of cases, occupation or an indication of social status was added as well. Below these details a half or a third of a page was left for clinical notes. If the patient was new to the practice, or had not been seen for a long time, notes were made in the newest of the ledgers in use. If the patient or his family had been seen recently, their notes would (if space permitted) be added to the previous entry in an earlier ledger. This is important in so far as it makes it impossible to determine the number of new episodes of illness or of total consultations a year. Thus the surviving ledger was begun in February 1757 and a new one was started some time in 1758; but records of visits were added to the earlier entries in the surviving ledger as late as 1764.

During the eleven months, 1 February to 31 December 1757, William Pulsford

\footnotetext{
${ }^{12}$ The main sources for constructing the details of the Pulsford family were:

The register of births, deaths, and marriages of the Cathedral Church of St Andrew's, Wells; and sepulchralia in the Cathedral, for which the author gratefully acknowledges the help of Mr Colchester, archivist to Wells Cathedral.

The following documents in Somerset County Record Office, Taunton:

Will of Benjamin Pulsford (Ref. DD/TD 29/43; DD/FS Box 42 c. 648); DD/SAS SE23 c. 795).

Will of William Pulsford (DD/SAS SE24 c. 795). Will of Lucas Pulsford (DD/FS Box 49 c. 648).

Abstract of title deed, William Pulsford, 1816. Obituary of Lucas Pulsford, Gentleman's

Magazine, 1819, 89(2): 92. Obituary of Benjamin Pulsford, Sherborne Mercury, 20 September 1784.

A. Peterkin and W. Johnstone, Roll of commissioned officers in the medical services of the British army 1660-1960, edited by Sir Robert Drew, 2 vols., London, Wellcome Historical Medical Library, 1968. Bailey's British Directory, 1784. Universal British Directory, 1793-98. Samuel Foart Simmons, Medical Register, London, 1780. W. Phelps, The history and antiquities of Somersetshire, 1839, vol. 2.

${ }^{13}$ Bailey's British Directory, 1784, includes under 'Wells, Somerset' "William Pulsford-Ironmonger".
} 
recorded in this ledger attendance on 212 individuals or families for 334 separate episodes of illness. There were, on average, about three follow-up consultations for every episode. Assuming that half as many consultations during 1757 were recorded in another ledger which has not survived, it can be estimated that William Pulsford carried out at least 1500 consultations in the eleven months of 1757 . Fees charged and payments received (not always the same) were recorded haphazardly, and usually payment was indicated by a pen-stroke through the whole entry.

Medical men are notorious for impatient untidiness in their record-keeping. The ledger was no exception, particularly as far as fees and payments were concerned. Fortunately, however, William Pulsford appeared to take a delight in recording clinical detail in a memorable, sharp, and often pungent personal style. The evidence of William's authorship rests largely on the handwriting. There are three distinct hands, easily distinguished. One is that of a Thomas Ogden who, following the premature death of William, was brought in to play the part of accountant and estimate the monies owing to William's estate and to Benjamin Pulsford, the surviving partner, respectively. The vast majority of entries-all the case notes, as well as most of the entries concerning fees-are in one hand. It seems clear that it was the hand of the younger partner, William Pulsford; it was his ledger and his alone. The third hand, that of Benjamin Pulsford, consists of brief notes, all dating from the period after William's death and concerned solely with fees paid or unpaid. The reason is clear. William, who had been diligent in his clinical notes, was often careless in recording charges made or fees received. Therefore, Benjamin had the task of going through the ledger after William's death to note what was still owing to the practice, as it was common for bills to be paid not only several months, but often several years, late. ${ }^{14}$ Hence the numerous entries to the effect "Bill Pulsford said he was [or was not] paid for this". They provide the firmest evidence that William Pulsford was the owner of the ledger.

The ledger is therefore the clinical and financial record of a young surgeon in country practice, keen, energetic, but relatively inexperienced. Margaret Allen ${ }^{15}$ in her account of the Pulsfords also concluded that William was the author of the ledger, but suggested that he acted as book-keeper, entering both his own and his uncle's cases. This is most unlikely. The nature of the entries shows clearly that the writer was describing things he had seen for himself and decisions he alone had made. Sometimes he and his uncle attended together (as, for example, when a major operation was performed) but otherwise there is never a hint that he is.describing the practice of the senior partner.

\section{III}

It is now widely recognized that the titles and designations of medical men in the eighteenth century often bore little relationship to the nature of their practice. ${ }^{16}$ The

\footnotetext{
${ }^{14}$ For example, a shopkeeper and his wife and children treated for five episodes of illness in 1757, five more in 1758, and seven in 1759, paid their bill in July 1767.

${ }^{15}$ Allen, op. cit., note 8 above.

${ }^{16}$ See, inter al: J.F. Kett, 'Provincial medical practice in England 1730-1815', J. Hist. Med., 1964, 19: 17-29. And for an earlier period, but making this point with particular force about provincial practice:
} 


\section{Provincial medical practice in eighteenth-century England}

classical model of a pre-nineteenth-century profession divided hierarchically into three distinct groups of physicians, surgeons, and apothecaries, each adhering strictly to their rightful spheres of practice, had little application to provincial practice. To an increasing extent, one finds the commonly adopted designations of medical men were such as "surgeon, apothecary, and man-midwife", or even "physician and surgeon". There was nothing inherently illogical in such titles. Medicine was not, from the practical point of view, regarded as so immense that no individual could encompass the whole of it.

The kinds of factors that determined the actual manner of practice cultivated by an individual were not only varied, but essentially opportunistic. These factors included, for instance, temperament and personal preference, family background and education, and apprenticeship, together with any other form of medical training. But the most telling factor was commercial opportunity. If there was no competition at all-if the practitioner was alone in his district-he was forced to practise all branches of medicine whether he was entitled physician, surgeon, or apothecary. His position was that of Robert Young, a naval surgeon in 1797, who remarked in his journal that, whatever his rank or title, the occupation of a naval surgeon was that of physician, surgeon, and apothecary rolled into one. ${ }^{17}$ Most provincial practitioners practised to some extent most branches of medicine, but individual examples demonstrate the extent to which their choice was determined by competition.

John Barr, for example, described as "a canny Scot", came south to Birmingham armed with both a surgical and a medical diploma from Edinburgh. Finding that physicians were thick on the ground in Birmingham he "kept his higher diploma in retentis", cultivated a practice amongst the Unitarians as surgeon and general practitioner, and made a fortune. ${ }^{18}$

Richard Kay (1716-51) was an example of a practitioner who practised all branches of medicine to the fullest extent on the basis of an apprenticeship to his father, a pupilship to Mr Steade the apothecary to Guy's Hospital, and attendance while in London at a course of surgical lectures and two courses of midwifery under Smellie. For that period it was a comprehensive training, and it is interesting to find that Kay referred to himself on one occasion as a physician and on another as surgeon and physician. ${ }^{19}$ Richard Smith junior (1772-1843) was a surgeon who undertook the care of all medical cases if patients chose to employ him, and regularly dispensed medicines from his house..$^{20}$

Thomas Baynton of Bristol (1761-1820) insisted on being called surgeon, like his father before him, but his practice embraced physic and a large amount of

R. S. Roberts, 'The personnel and practice of medicine in Tudor and Stuart England. Part 1: The provinces', Med. Hist., 1962, 6: 363-382.

${ }^{17}$ Surgeon's Journals, at the Public Record Office, Kew (Ref. HMS Ardent, 1797-98, ADM 101 85/7).

${ }^{18}$ Birmingham Record Office, Birmingham Public Library, Notes and Queries, 15, 22, and 29 June 1870.

${ }^{19} \mathrm{~W}$. Brockbank and F. Kenworthy (editors), The diary of Richard Kay (1716-51) of Baldingstone near Bury. A Lancashire doctor, Manchester, Chetham Society, 1968, 16; and W. Brockbank and M. L. Kay, 'Extracts from the diary of Richard Kay of Baldingstone, surgeon (1737-50)', Med. Hist., 1959, 13: 58-68.

${ }^{20}$ Bristol Infirmary biographical memoirs, vol. 2, pp. 152-153, memoirs of Richard Smith jun. Bristol Record Office, The Council House, Bristol. 
midwifery-in fact, all the business he could obtain because he was a vain, smoothtongued man, with an inordinate love of money, even for the eighteenth century. ${ }^{21}$ Mr Misters of Shipston-on-Stour in Worcestershire was also described as a "surgeon" but his records (1776-81) show that the vast majority of his cases were medical and most of his income was derived from the dispensing of drugs. ${ }^{22}$

James Clegg of Chapel-en-le-Frith (1679-1755) was a Dissenting minister who undertook the practice of medicine after learning the rudiments of physic from a physician in Macclesfield. When threatened with prosecution in the spiritual courts for obtaining access to patients through his privileges as a minister, he bought an MD from Aberdeen in 1729 and became, by this process, a "legitimate" physician. Most of his practice was medical but he treated surgical cases when he had to and he practised pharmacy-that is, he dispensed medicines for his patients. ${ }^{23}$

William Broderip of Bristol, with his carriage and coachman and his grand country house, was a prime example of a successful apothecary, although his vanity led him to adopt the title "Dr" and pretend to be a physician in the outlying districts. ${ }^{24}$ From the manner in which they practised there was little difference between Clegg and Broderip. Both practised physic and pharmacy, but Broderip in his best years made by far the higher income.

The Pulsfords provide an example of a practice in which, although many medical cases were treated, the emphasis was mainly surgical. The extent of midwifery in the practice is uncertain. Benjamin Pulsford contracted with the overseers of the Inparish of Wells to provide obstetric care for the poor, and also undertook some private cases. There is no evidence that William Pulsford undertook obstetrics, but there may have been a separate ledger for obstetrics which has not survived. The Medical Register for 1780 lists five surgeons and apothecaries in Wells in addition to the Pulsfords. There was also at least one physician-Dr Harington ${ }^{25}-$ who is $^{2}$ mentioned in the ledger. Thus competition in the field of physic was strong, and possibly in obstetrics as well, while the Pulsford practice was long-established and probably well recognized for its preference for surgery.

Surgery in the eighteenth century was defined as the treatment of external diseases and all which required "manual interference". It included operations, the reduction of fractures and dislocations, the dressing of wounds and ulcers, the removal of teethrand the opening of abscesses, and all eye and skin diseases. Surgeons also had a virtual monopoly in the treatment of venereal disease. Midwifery was not considered exclusively a surgical activity and was undertaken by some physicians, surgeons, and apothecaries as well as by the few who made it their chief activity as men-midwives or accoucheurs.

\footnotetext{
${ }^{21}$ Ibid., vol. 2, pp. 1060-1080. See also, J. A. Nixon, 'Thomas Baynton 1761-1820', Proc. R. Soc. Med., 1914-15, 8: 95-102.

${ }^{22}$ The account book of Thomas Misters of Shipston-on-Stour. Wellcome Institute Library, London (Ref. MS 3584).

${ }^{23}$ V. S. Doe, The diary of James Clegg of Chapel-en-Frith 1708-1755, 3 vols., Matlock, Derbyshire Record Society, 1978-81.

${ }^{24}$ Bristol Infirmary biographical memoirs, op. cit., note 20 above, vol. 2, p. 157.

${ }^{25}$ Henry Harington (1727-1816) MA Oxford 1752, MD 1762, established himself as a physician in Wells in 1753 and moved to Bath in 1771 . He was a noted composer of music. On two occasions recorded in the Pulsford ledger he arranged for William Pulsford to sound a patient for suspected bladder stone; on neither was a stone present.
} 
The main results of an analysis of this ledger are shown in the accompanying tables. Tables 1 and 2 are based on an analysis of the whole ledger; the remainder are based on a sample consisting of all the cases recorded as having been seen in the year 1757 .

TABLE 1. OCCUPATION OR SOCIAL STATUS OF PATIENTS AS RECORDED IN THE WHOLE OF THE LEDGER FROM 1 FEBRUARY 1757 TO $c .1764$

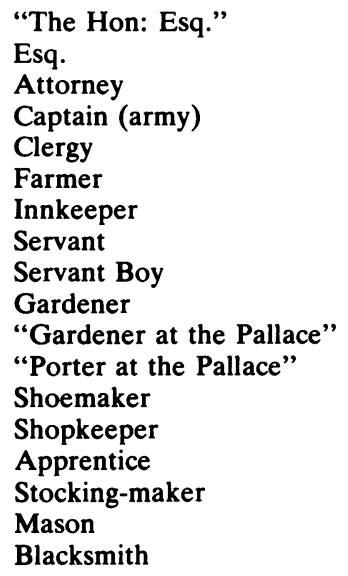

“Serjeant” (army)
Clerk
Silversmith
Carpenter
Millwright
Tanner
Peruke-maker
Glover
Hatmaker
Organ-builder
Glazier
Brazier
Thatcher
Wheelwright
Stay-maker
Pipe-maker
Chandler

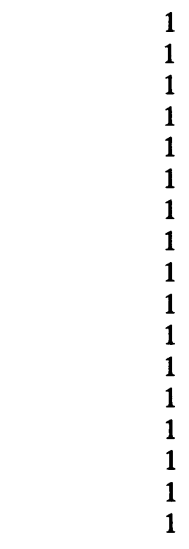

Total

Source: The ledger of William Pulsford, Somerset County Record Office, Taunton, Somerset, accession no: DD/FS Box 48.

TABLE 2. COUNTRY PATIENTS, LIVING ONE OR MORE MILES OUTSIDE WELLS. THE DISTANCE FROM THE CENTRE OF WELLS TO THEIR HOMES WHEN THEIR ADDRESS WAS RECORDED

Distance
1 to 2 miles
2 to 3 miles
3 to 4 miles
4 to 5 miles
5 to 6 miles
6 to 7 miles
7 to 8 miles
8 to 9 miles
9 to 10 miles

Number of Patients

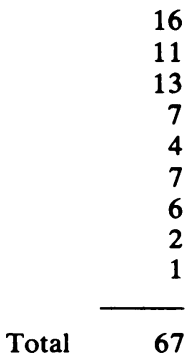

Source: as for Table 1. 


\section{Irvine Loudon}

Table 1 shows the patients' occupations, which were recorded in about one-quarter of the cases. It shows a predominance of tradespeople rather than the gentry or the professions. It is probable that the upper levels of society in Wells would either have employed the physician, or, if a surgeon was required, would have employed the senior partner, Benjamin Pulsford, for his greater experience. In addition, the Pulsfords were appointed as parish surgeons to the In- and Out-parishes of Wells, the parishes of Wookey and Holcombe, and possibly other parishes as well. These appointments contributed a considerable amount to their income and suggest that in this area the old poor law system provided a reasonable standard of medical care for the poor.

Table 2 demonstrates the distance some of the patients lived from the centre of Wells; but not all of them were necessarily visited at home. There is clear evidence that some attended at William Pulsford's house,${ }^{\mathbf{2 6}}$ and others stayed in Wells during a course of surgical treatment. On several occasions, there is a record of the overseers of the poor paying for a patient from an outlying area to be boarded in Wells for the purpose of receiving treatment. For example, at the request of the overseers of the poor for the parish of Holcombe: "We went to Holcombe to take off a leg for Mary Pearl on Acct. of the bones of the Foot having been for a long time Carious, but finding the woman able to be brought to Wells, defer'd the operation till the 21st when it was performed at Thos: Maynard's in Prison Row." Likewise, in November 1759 , an operation for fistula-in-ano was performed on the orders of the overseers in Wells: ". . . the man was an alien, but maintained during an illness soon after by the parish".

Table 3 shows the 334 episodes of illness recorded in the ledger during 1757, but once again it must be emphasized that this was not the complete list for that year, since a number of cases were almost certainly recorded in a previous ledger. It provides, however, a representative sample. The diagnostic terms used in the table are, with few exceptions, those recorded by William Pulsford in the ledger. The exceptions are "skin eruptions" for some ill-defined skin conditions, and "dental disorders" for extractions and dental abscesses, etc. "Oedema" is an interpretation of a clinical description.

There are two main features of this table. The first is the predominance of surgical cases; the second, the minor nature of many of the cases. Surgery in the preanaesthetic era is usually pictured as a series of grim and dreadful operations of unimaginable pain. As Porter recently described it: “. . . in the age of agony before antiseptics and anaesthetics, surgery was limited to simple, quick or desperate operations such as amputations, removing bladder stones and setting fractures". ${ }^{27}$ Indeed, this view has sometimes been combined with the belief that our predecessors in this period were either less sensitive to pain or much more stoical than ourselves, accepting or ignoring minor complaints and only consulting surgeons as a last resort. The evidence of the Pulsford ledger provides no support for such a view; instead it provides a more prosaic picture. Most of William Pulsford's income was derived from

\footnotetext{
${ }^{26}$ Benjamin Pulsford in his will dated 1784 refers to the room in his house where he saw patients as his "surgery". This is, in the author's experience, the earliest such use of the word.

${ }^{27}$ Roy Porter, English society in the eighteenth century, Harmondsworth, Penguin Books, 1982, p. 303.
} 
TABLE 3. THE DIAGNOSTIC GROUPS OF ALL CASES RECORDED IN HIS LEDGER BETWEEN 1 FEBRUARY 1757 AND 31 DECEMBER 1757, BY WILLIAM PULSFORD

Accidents and injuries (see Tables 4 \& 5)

Sore throats, ulcerated throats, and ulcerated tonsils and quinsies

Erysipelas

Smallpox

Fever

Venereal Disease

Skin eruptions

The itch

Herpes of the lip

Sore legs (mostly ulcers of the legs)

Boils and abscesses

Abscess of the ear

Soreness, induration, or abscess of the breast

Whitlow

Inflamed arm following venesection

Fistula-in-ano

Perianal abscess

Inflammatory swellings

Swellings of the neck including scrofula

Dental disorders

Ulcers of the mouth

Hernia

Phymosis and paraphymosis

Hydrocoele

Piles

Corns on the feet

Warts

Ganglion

Haematoma

Suppression of the urine

Sore eyes

Albugo

Pain in the limbs

Caries of bone

Incisted [sic] tumor of lip

Cancer of breast

Cancer of tongue

Nose bleed

Oedema, cause obscure

Inoculation against smallpox

Diagnosis obscure or uncertain

\section{Glossary}

The itch-scabies.

Phymosis and paraphymosis-inflammatory swelling of the foreskin.

Hydrocoele-accumulation of fluid surrounding the testicle.

Ganglion-cystic swelling arising from the tendon, usually on the back of the hand or wrist.

Haematoma-a tumour consisting of an extravasation of blood.

Albugo-a scar on the cornea following a corneal ulcer; smallpox was here a common cause.

Source: as for Table 1. 


\title{
Irvine Loudon
}

the treatment of minor injuries, boils and abscesses, skin rashes, warts, whitlows, piles, and sore eyes. External sepsis of pyogenic tuberculous or syphilitic origin affecting the skin, lymph glands, or bones and joints, was common; and surgical care for minor complaints was sought not just by an effete gentry to whom a surgical fee would be immaterial, but by all social classes. Chronic infections and ulcers, especially the ubiquitous leg ulcers, ${ }^{28}$ required repeated attendances over weeks or months, with the compensation of providing a steady source of income. For example, Mr Salmon (status or occupation not recorded) was treated from February 1757 until October 1758 for a chronic suppuration with ulceration of the leg; and a Mr Bethy's daughter in 1757 "was near five months underhand [with] a sore on her inner ancle". Pulsford carried out a few amputations, but such major surgery alone would never have provided a living. Pulsford, and indeed most surgeons of the period, depended for their living on routine procedures that would, in most instances, now be carried out by the nurse of a general practice or a casualty department. ${ }^{29}$

The common picture of the eighteenth-century surgeon frequently engaged in major operations should be modified. Instead, a picture should be substituted of a surgeon such as William Pulsford making his rounds on horseback with two large saddlebags containing ointments, lotions, bandages, and plasters, as well as instruments. ${ }^{30}$ In the periods between urgent calls, his time would be spent on the tedious and often smelly business of draining pus from infected wounds and abscesses and dressing chronically infected and suppurating lesions. William Chamberlaine was explicit on the realities of the surgical life when he warned the apprentice surgeon:

\begin{abstract}
Are you too fine a gentleman to think of contaminating your fingers by administering a clyster to a poor man, or a rich man, or a child dangerously ill when no nurse can be found that knows anything of the matter? This is a part of your profession that it is as necessary for you to know how to perform as it is to bleed or to dress a wound. Or are your olfactory nerves so delicate that you cannot avoid turning sick when dressing an old neglected ulcer; or when, in removing dressings, your nose is assailed with the effluvia from a carious bone? If you cannot bear these things, put Surgery out of your head and go and be apprentice to a Man Milliner or Perfumer. ${ }^{31}$
\end{abstract}

This is a memorable account of the true nature of surgery, and it has an important bearing on the social status of the surgeon. The physician, unless as a country doctor he had to treat all conditions, scarcely came into physical contact with his patient except to feel the pulse. He could, and usually did, stand aloof; his dignity depended on it. Surgery, on the other hand, was emphatically a manual craft, unsuitable for refined and delicate sensibilities. Although surgery contained a large element of

\footnotetext{
${ }^{28}$ I. S. L. Loudon, 'Leg ulcers in the eighteenth and early nineteenth century', J. R. Coll. Gen. Practnrs, Part 1, 1981, 31: 263-273; Part 2, 1982, 32: 301-309.

${ }^{29} \mathrm{~A}$ nurse was occasionally employed by William Pulsford, but usually only in the final period of healing. It is not known whether she was paid directly by the patient or by Pulsford.

${ }^{30}$ This was also true of hospital surgery in the eighteenth century. For example, out of 152 surgical in-patients admitted to the Nottingham General Hospital in 1795-97 under the care of Mr John Wright, honorary surgeon to the hospital, only four underwent major or "capital" operations. A large majority were admitted with ulcers and inflammations treated by local applications, dressings, diet, and bed-rest. University of Nottingham Library: manuscripts department. 'Patients' treatment book 1781-1801' (Ref. Uhg 0 1).

${ }^{31}$ William Chamberlaine, Tirocinium medicum: a dissertation on the duties of youth apprenticed to the medical profession, London, 1813.
} 


\section{Provincial medical practice in eighteenth-century England}

coarseness, its effectiveness lay not so much in the dramatic realm of so-called heroic surgery as in the simple non-operative measures. At this prosaic level the eighteenthcentury surgeon could relieve and cure many common complaints. It is probably true to say that the intervention of the plain country surgeon like William Pulsford, exercising his skill with fractures, dislocations, abscesses, and toothache, achieved far more than the most wise and skilful physician. Campbell, the author of The London tradesman (1747), would have shared this view. He was frankly scornful of the effectiveness of physicians, but regarded the surgeons much more favourably. His description of the nature of surgical practice corresponds closely to the practice of William Pulsford, and he believed that "a properly qualified" surgeon could not only obtain a "lucrative employment", but, unlike the physician, deserved it. "An ingenious Surgeon, let him be cast on any Corner of the Earth, with but his case of Instruments in his Pocket, he may live where most other Professions would starve." 32

Probably the greatest part of William Pulsford's time was spent in the tedious treatment of chronic infective conditions, but the most common category-and the one in which the surgeon was able to offer most effective treatment-was accidents and injuries. These ranged from minor sprains to severe injuries, and the nature and cause of these is shown in Tables 4 and 5. Injuries associated with horses were common and often severe, emphasizing, like the evidence from the diaries of James Clegg and Richard Kay, that horse transport in the eighteenth century was far from safe. Accidents with farm implements were also common and one was fatal:

\footnotetext{
October 12th 1757. Mr Giblet of Westhay

Mr Giblet had the misfortune to receive a wound by a Scyth thro. the Caps. ${ }^{r}$ Lig. ${ }^{t}$ of the Knee:

Mr Rock of Glaston[bury] was empl ${ }^{d}$. ab ${ }^{t}$. three weeks after he rec ${ }^{d} \cdot y^{e}$ Accid $^{t}$. We saw him, laid open on a Sinus on the Side on the Thigh and made a counter opening on the side of the Pat.[ella]. He was in a bad low State and died a few days after.

vid. itin. Rec $^{\mathrm{d}}$. in full 5. 0.0.

[vid. itin. = seen on a "journey", i.e., on the round of visits.]
}

The treatment of wounds and lacerations, a frequent occurrence in the practice of all surgeons, was a much-debated subject in the eighteenth and early nineteenth centuries. At the centre of the debate was the question whether it was safe to bring the edges of a wound together and encourage healing by primary intention, or whether the wound should be kept open and suppurating by the insertion of "tents" to allow slow painful healing from below by secondary intention, leaving an ugly scar. Broadly speaking, the end of the century saw the abandonment of the secondary method, leaving the question of how primary healing was to be encouraged. The alternatives were by stitching or by strips of plaster-the latter being known as the "dry suture". Stitching carried the extra risk of sepsis from the suture material, although it produced a neater result. ${ }^{33}$ It is interesting to find that William Pulsford in 1757 not only favoured primary wound closure but used stitches with apparent

\footnotetext{
${ }^{32}$ R. Campbell, The London tradesman, London, 1797.

${ }^{33}$ L. Heister, A general system of surgery. trans. from the German, 7th Ed., London, 1760. John Bell, Discourses on the nature and cure of wounds, Edinburgh, 1795, and The principles of surgery, vol. 1, Edinburgh, 1801. John Hunter, $A$ treatise on the blood, inflammation and gun-shot wounds, 2 vols., London, 1812. (The work was completed in 1792.) Samuel Cooper, $A$ dictionary of practical surgery, 7 th Ed., London, 1838, has an excellent account of the varying views on the treatment of wounds.
} 


\section{Irvine Loudon}

success even in cases of inherent difficulty:

July 71759 Rob $^{t}$ Reed by St John's Bridge

Cut his throat (being lunatick) but missed $y^{e}$ Large Vessels-I sew ${ }^{d}$ it up \& cured him soon. Charged a guinea only.

Aug 71758 White, Shoemaker

His son fell from a Nut-Tree and rip ${ }^{d}$ open $y^{e}$ Scrotum, so that one Testicle hung out, which I returned, stitch ${ }^{d}$ up $y^{e}$ Scrotum and soon cured him.

Sept 2 1758, Magor of Dinder

Cut $y^{e} 1$ st phalanx of his Forefinger almost off $w^{\text {th }}$ an Hatchet, but using a suture we saved the Finger and he has $y^{e}$ use of it.

\section{TABLE 4. ACCIDENTS AND INJURIES}

Bruises and sprains

slight

severe

Wounds and lacerations

slight

severe

Head injuries

(definite fractured skull)

Fractures and dislocations

Burns

Eye injuries

Wasp sting

Source: as for Table 1.

\section{TABLE 5. THE CAUSES OF ACCIDENTS AND INJURIES}

Not recorded

Horses-falls while riding, or being kicked by horses

Falls (from ladders, trees, etc.)

Fighting

Accidents with guns or gunpowder

Dog-bite

Accidents with:

Hatchet

Hay knife; scythe; tenterhook; millstone;

fall of timber; glass; wasp sting; catgut flying into eye while mending musical instrument 1 each

Total 91

Source: as for Table 1. 


\title{
Provincial medical practice in eighteenth-century England
}

The treatment of accidents was the field in which William Pulsford appears to have worked with most skill and confidence, the clinical notes showing a considerable knowledge of the pathology and treatment of the common fractures and dislocations; on this alone, were it necessary to do so, he could have justified his occupation to posterity.

Major operations were rare; in fact there are only five recorded in the ledger; two amputations, two removals of a breast tumour, and one trephining in the case of a fractured skull. These amounted to about one per cent of the total number of cases recorded between 1757 and 1764 . Once, he advised an operation for a hernia he believed to be strangulated, but the patient-wisely-refused, and recovered. On another occasion, he also met refusal:

\begin{abstract}
Mr Moon at Callow Hill
He was br ${ }^{t}$ here by Mr Gale having been thrown down by a Bull. There was a Small Wound on his head which I dress ${ }^{d}$, but, $c^{d}$ not prevail on him to be bled, as he seem ${ }^{d}$ greatly disordered in his senses by the Shock; the next day my Uncle being sent for down [sic] thought he felt a Fracture, but they $w^{d}$ not consent to have proper Care taken. NB This man lived but did not recover his Senses or Speech properly.
\end{abstract}

Eye conditions were common and there are several entries referring to smallpox as a cause of loss of vision amongst children, as in the case of a daughter of an innkeeper:

Took [her] in hand with an albugo after $y^{\mathrm{e}}$ Smallpox. Mr Keate had been her surgeon for some time. After the use of an ophthalmic powder for some time, the ch ${ }^{\text {ld }}$ went into the Country for a week and returned with only a depression where the Cicatrix was without any appearance of an albugo, but the eye soon after upon their omitting $y^{e}$ use of the powder grew cloudy.

An albugo is a corneal scar, of which smallpox was one cause. The same child appears, two years later, in the ledger when her father "being in liquor he threw a board and cut [her] head in an ugly manner".

Amongst the minority of medical cases treated by William Pulsford much the most common were sore throats, and it seems there was an epidemic of them in Wells in 1757-59, which, with good reason, caused Pulsford to feel alarmed and helpless. These cases were described most often as sore throat or inflamed sore throat, but also on numerous occasions as ulcerated sore throat or ulcerated tonsils. The rash of scarlet fever was never recorded, and the clinical descriptions do not suggest diptheria in spite of one reference to "Dr Huxham's species" of sore throat. ${ }^{34}$ Instead, the concurrence of erysipelas (once entered in the ledger as "St Anthony's fire of the face") suggest an epidemic streptococcal infection. The descriptions correspond to those of Fothergill, who described $A$ sore throat attended with ulcers in London in $1748,{ }^{35}$ and noted its continuation as an "epidemic sore throat in both children and adults" in $1755 .{ }^{36}$ Many of the cases were mild, but a minority provoked more alarm than any other condition. Serious cases occurred amongst adults as well as children. Mr Vincent, a blacksmith, was "almost suffocated by a sore throat" in

\footnotetext{
${ }^{34} \mathrm{John}$ Huxham, $A$ dissertation on the malignant ulcerous sore throat, London, 1757.

${ }^{35} \mathrm{John}$ Fothergill, An account of the sore throat attended with ulcers, London, 1748.

${ }^{36}$ John Fothergill, Gentleman's Magazine, 1755, 25(2): 343. Here the concurrence of sore throat and erysipelas was noted, similar to the outbreak in Wells in 1757-58.
} 


\title{
Irvine Loudon
}

June 1759. In May 1758, "Mrs Giles daughter had $y^{e}$ worst ulcer ${ }^{d}$ Throat with $y^{e}$ most alarming symptoms I ever saw in any Person, who recovered." The infection spread through the Giles family. In October 1757, he wrote of Mrs Plympton of Wester Compton: "Took in hand her daughter $\mathrm{w}^{\text {th }}$ an excessive bad ulcer ${ }^{d}$ throat, Dr Huxham's species. There seemed to be but the least chance for Life, yet we recovered her."

William Pulsford may have been alarmed because of a death, both tragic and unexpected, early in 1757 . The patient, the wife of a stocking-maker, was named Mrs Poynting, and the note is quoted in full to demonstrate the quality of the clinical data in the ledger:

\begin{abstract}
Mrs Poynting sent hither about three o'clock in $y^{e}$ afternoon; I then found her complaining of a slight soreness of her Throat $w^{\text {th }}$ which she was seized $w^{\text {th }}$ a chill some time in the Morning. The Uvula was somewhat relax'd but there was not the least Appearence of Danger as she had no Fever. I sent her D. [decoction] Rubra, was called to her at One in $\mathrm{y}^{\mathrm{e}}$ Morning and found her to Appearence in an Hysterick Fit. She was convuls'd and her Pulse from being very strong, and uncommonly quick, ceas ${ }^{d}$ at once, and she Dyed before $I c^{d}$ have been $w^{\text {th }}$ her two minutes. She was seven months gone $\mathrm{w}^{\text {th }}$ child. ${ }^{37}$
\end{abstract}

And this was not the only fatality from a throat infection. In the same month, February 1757, Mr Savage of Priddy "who had an incapacity of Swallowing which seemed to proceed from some Disease of the Glands, as he spit up immense quantities of viscid phlegm" was treated with blisters and plasters while he stayed at an inn in Wells. He returned home with "a blister for each arm and one for the throat ... where he died a Day or two afterwards".

To summarize the clinical practice of William Pulsford and emphasize the essentially mundane nature of country surgical practice in the eighteenth century, the following is a list of the new cases recorded in the ledger for the week commencing 6 March 1757:

A servant boy with inflamed tonsils; D.(decoction) rubra supplied.

A chandler's wife with a "bad back" for which an embrocation was given.

A child with a hernia, treated with a plaster.

A woman given ointment for her piles.

An apprentice with a "bad knee", plastered.

A woman with a dental abscess.

A silversmith with an inflamed arm, bled once and the arm dressed twice daily: cured in a fortnight.

A millwright with an abscess of the ear treated with drops of balsam in spirit.

An innkeeper's wife with a fractured fifth metacarpal.

A visit to a sick woman at Coaxley on the order of the overseers of the poor; no diagnosis or treatment recorded.

A man with a "slow fever" and stomach pain. "I cut him an issue and some days after ordered a blister."

\footnotetext{
${ }^{37}$ While it is obviously impossible to be certain of the cause of death in this case there are features of the story which would fit an acute Haemophilus influenzae infection with epiglossitis and/or laryngeal obstruction, suggested by the short interval between onset and death, and the "relaxed" (? oedematous) uvula.
} 


\section{Provincial medical practice in eighteenth-century England}

A farmer's wife with an inflammation of the breast "dress ${ }^{d}$ until it suppurated and broke".

A girl with an inflamed throat "treated with D. Rubra and very soon recovered". Five deaths were recorded in the ledger. Two were from throat infections, one from (presumed) sepsis from a severe leg wound, and two others: a patient who had been catheterized several times for "suppression of urine" and was found dead on a routine call; and "Mrs Parsons [who] broke her thigh two thirds up at the age of 87 . I reduced it and a strong callous formed; but the old woman grew so fond of her bed that she never got up much afterwards-mortified her back and died of old age."

\section{$\mathbf{V}$}

The size of the fees charged by the Pulsfords was determined by a number of factors. For example, fees were higher for difficult and skilled procedures; more was charged for an amputation than for extracting a tooth. The more attendances, the larger the fee, and this, although obvious, was important because so many cases required frequent attendance over long periods. If the patient was visited at home, the greater the distance the larger the fee, although there was a tendency to charge a flat fee for most "journeys" rather than to calculate strictly according to distance. Outcome-that is, success or failure of treatment-had little effect on the size of the fee. Finally, the social and occupational status of the patient could influence the fee charged, but on the whole it is interesting how little effect this had. Where comparable cases are recorded in the ledger, there was generally little variation in the fee over a wide range of occupations. Substantially higher fees were usually charged only at the uppermost end of the social scale. For example, $10 \mathrm{~s} .6 \mathrm{~d}$. was the Pulsfords' standard charge for inoculation against smallpox; but the wife of the Hon. George Hamilton Esq. was charged four guineas. Conversely, fees were not lowered for treatment paid for by the overseers of the poor, or for the lower income groups who paid for themselves. Sarah Cole of Lytton, who was so circumstanced it was believed she was "on the parish", was treated for an oral infection arising from "rotten teeth" which had to be extracted. The overseers refused to pay, and William Pulsford charged her two guineas, insisting on payment by monthly instalments of $5 s$ until it had all been paid.

The interpretation of individual fees is difficult for two reasons. First, bills were often allowed to accumulate over months or years and the fees were not itemized, but recorded as a final total. For example, Farmer Hill of Hinton paid a bill of fifteen guineas in May 1759, which covered a whole series of visits since March 1757. Second, there was what might be called the "hidden economy": payment in goods rather than money. There is one clear example in the ledger where a part-payment was made in the form of a load of hay, and when William Pulsford "settled accounts" with Mr Vincent, his blacksmith, it seems likely they compared what they owed to each other and settled the difference. Richard Smith in Bristol recorded how in the 1790 s he was similarly paid in goods by a patient who was a woollen-draper. ${ }^{38}$ Such transactions would only be entered in the ledger occasionally and may have been

${ }^{38}$ Bristol Infirmary biographical memoirs, op. cit., note 20 above, vol. 2, pp. 152-153. 
more common than the records suggest.

TABLE 6. FEES CHARGED AND RECEIVED BY WILLIAM PULSFORD FOR VARIOUS SURGICAL AND MEDICAL TREATMENTS. SELECTED EXAMPLES.

Accidents and injuries

Fee charged

Bruised arm from being kicked by a horse

5s. Od.

Bruised head from a fall from a horse

A farmer treated for a fractured fibula

10s. $6 d$.

10s. $6 d$.

Reduction of a dislocated shoulder

11s. $6 d$.

Fractured clavicle from firing a gun

Farmer's wife: "cut artery, difficult to stop"

Fractured skull; perforator used on cranium

Bruised leg from a fall from a ladder

Child: dislocated wrist from a fall from a tree necessitating three journeys

11s. $6 d$.

7s. $6 d$.

15s. $6 d$.

$1 \mathrm{gn}$.

$1 \frac{1}{2}$ gns.

2 gns.

5 gns.

5 gns.

Millworker: "Top of finger almost cut off: sewed back on"

5 gns.

Wound of thigh from scythe: operation, patient died

A shoemaker's sons: for one, the stitching back of a ripped-open scrotum, and for the other, a broken thigh "cured without lameness"

Charge for both

10 gns.

\section{Operations}

Child: haematoma of skull opened

5s. Od.

Gardener's child; abscess of neck opened

Tumour in neck opened

Farmer: abscess in groin opened

$7 s .6 d$.

10s. $6 d$.

10s. $6 d$.

Inoculation against smallpox:

generally

occasionally

10s. $6 d$.

Abscess of breast opened

Shoemaker's wife: removal of breast tumour

Tumour (? T.B. glands) removed from neck

"Took an uncommon substance" from a child's side

Removal of breast tumour

An apprentice: fell, fractured skull, trephined and "ten pieces of bone removed"

Amputation of leg (paid by overseers of the poor)

1 gn to 4 gns.

1 gn

$1 \frac{1}{2}$ gns.

$£ 111$ s. 6 d.

5 gns.

5 gns.

5 gns.

7 gns.

Leg ulcers and sore legs

Venesection and dressings for an inflamed leg

Housemaid treated for leg ulcers

"Cured a sore on the foot"

Treatment of a "foul ulcer on the leg from a dog-bite"

"Ulcer on ancle" treated, "cured in 6 weeks"

Farmer treated for 4 months for a "sore leg"

"Ulcer on ancle" treated for nearly 5 months

"Sinuous ulcer on leg"; operation to "cut integuments"; thirteen journeys

Inflamed leg with ulceration, treated intermittently over 2 years and 6 months

7s. 6 d.

10s. $6 d$.

10s. $6 d$.

$1 \mathrm{gn}$.

2 gns.

2 gns.

$2 \frac{1}{2}$ gns.

$2 \frac{1}{2}$ gns.

14 gns.

Miscellaneous conditions

Embrocation supplied to a farmer

5s. $0 d$.

"Strained shoulder" treated

Child treated for tonsillitis

5s. Od.

7s. $6 d$.

8s. $0 d$.

Farmer's wife, inflamed breast: 'numerous dressings"'

Child treated for many small abscesses following smallpox

10s. $6 d$.

Albugo (corneal ulcer) following smallpox, treated with eye drops

10 s. $6 d$.

10s. $6 d$.

Woman treated for pains in the neck

"Phymosis and a gleet"

10s. $6 d$. 


\section{Provincial medical practice in eighteenth-century England}

Miscellaneous conditions (contd.)

Fee charged

Farmer treated (medically) for a hard tumour in the neck

$1 \mathrm{gn}$.

A woman with gross oedema of the legs and abdomen "treated by scarification"and two gallons discharged

A mason: "mortification of the sacrum, dressed twice a day"

An innkeeper's wife treated for "putrid mouth ulcers"

A peruke-maker: 8 minor episodes of illness in the family over a period of 3 years

An attorney: 12 minor episodes of illness in the family treated over a period of seven years

$1 \frac{1}{2}$ gns.

2 gns.

2 gns.

$£ 316$ s. Od.

10 gns.

Treatment paid for by the overseers of various parishes

Sore finger

Widow with "violent pains in the limbs"

5s. $0 d$.

10s. $6 d$.

Quinsy opened and pus discharged

Treatment of multiple abscesses

Treatment of large wound in the leg from a hatchet

10s. $6 d$.

$1 \mathrm{gn}$.

$1 \frac{1}{2}$ gns.

$1 \frac{1}{2}$ gns.

3 gns.

Treatment of a fractured leg

Venereal disease treated by mercury

Amputation of leg

5 gns.

7 gns.

Source: as in Table 1.

The most common fee charged by the Pulsfords, and also with few exceptions the lowest fee, was $5 s$. This was demanded for treating a hat-maker for a sore throat; a young woman with "the itch"; a farmer's wife whose inflamed breast was treated with a plaster; for opening an abscess, or for extracting a tooth. This minimum fee for a minor procedure represented perhaps half if not the whole of a week's wages for a hat-maker; medical care was not cheap. Only once did Pulsford record that he treated someone "gratis"..$^{39}$ Further examples of the fees charged are shown in Table 6 , but in spite of the quantity of financial data, it is impossible to be certain of William Pulsford's income. Following his death, an entry was made in the back of the ledger to the effect that $£ 45319 \mathrm{~s} .2 \mathrm{~d}$. was owed to William's estate and $£ 45815 \mathrm{~s} .0 \mathrm{~d}$. to Benjamin Pulsford. The basis of these calculations is uncertain. Probably, they refer to the total sums owing to the partnership at William's death; some had been owing for years. A further difficulty in estimating the profits of the partnership concerns the dispensing of medicines. Medical treatments are mentioned in passing in the clinical notes in the ledger but there are no prescriptions, no quantities supplied, and no charges specifically for medicines. It is certain that William Pulsford supplied medicines such as his almost routine "D.Rubra" for sore throats, and likely that there was a separate prescription book which included charges apart from those entered in the ledger. These charges could have formed a substantial addition to the practice income. Even if the probability of a separate prescription book is ignored, together with any "hidden" income in the form of goods, it seems likely that William Pulsford earned at least $£ 400$ a year.

If this estimate is correct, Pulsford earned his substantial income not from a highly specialized practice amongst the rich, scattered over a large area, but for the most part from ordinary simple surgical procedures in a practice of farmers, shopkeepers, and craftsmen living in, or close to, Wells. Moreover, he was in competition with at

${ }^{39}$ On another occasion it was noted that the patient was "poor" and there was no indication of a fee charged or received. This patient may also have been treated "gratis". 
least one physician, and at least two (and probably more) surgeon-apothecaries in the area. This provides the evidence of a substantial market for medical care and a willingness to pay Pulsford's substantial fees in preference to home remedies or less expensive unorthodox practitioners-although, no doubt, these were employed as well..$^{40}$ Moreover, the comparison, in terms of fees and income, between William Pulsford and Claver Morris is most revealing.

Claver Morris (1659-1726) was a graduate of Oxford University (MA 1682, MB 1685, MD 1691) and an extra-licentiate (1683) of the Royal College of Physicians of London. ${ }^{41}$ After a period in Salisbury, he moved to Wells where he remained in practice as a physician during the first quarter of the eighteenth century. His patients included a high proportion of the gentry and the rich, not only throughout Somerset, but also in Gloucestershire, Wiltshire, Devon, and Dorset. His impeccable qualifications and the social standing of his patients were those of a well-known and sought-after provincial physician of high repute. His house in the Liberty in Wells was larger and grander than Benjamin Pulsford's house at 5 New Street; but his fees and income were considerably lower than those of the Pulsfords. Claver Morris charged the poor $2 s .6 d$., the small tradespeople $5 s$., the substantial tradespeople $10 s$. $6 d$., and the gentry one guinea. It is estimated that his income from his practice was between $£ 100$ and $£ 150$ up to 1710 and then between $£ 200$ and $£ 300$ a year. Here we have the unexpected finding that the fees and the annual income of the well-known physician with a practice amongst the gentry and the aristocracy were substantially lower than those of the young surgeon, although there was only a gap of thirty years between the end of Claver Morris's practice and the beginning of the Pulsfords'.

\section{VI}

The contrast between the incomes of Claver Morris and William Pulsford may have been due partly to the number of patients seen. William Pulsford was busy and most of his patients were local, while Claver Morris travelled long distances. Nevertheless, one would have expected the sought-after physician to the rich to have charged substantially higher fees than the young local country surgeon; instead, the fees were much the same. This suggests three possibilities. First, that the Pulsfords' fees were due to inflation during the intervening period. This can be dismissed, because there is no evidence of a significant rise in the cost of living between 1700 and 1760 in England in general or Somerset in particular, and certainly not to the extent of the difference between the two incomes. ${ }^{42}$ Second, there is the possibility that either Morris or Pulsford were atypical practitioners; there is no evidence that

\footnotetext{
${ }^{40}$ William Pulsford tended to be equally scornful of the failures of other orthodox practitioners in his neighbourhood and the treatments he described as "old-women's remedies", used by the patients themselves or on the advice of friends or neighbours. Otherwise, there are no references in the ledger to unorthodox practitioners.

${ }^{41}$ E. Hobhouse (editor), The diary of a West Country physician, London, Simpkin Marshall, 1934.

${ }^{42}$ Gladys Bradford, 'Social and economic history [of Somerset]', in Victoria County History of Somerset, London, Constable, 1911, vol. 2, part 1, pp. 267-337. J. E. Williams, 'The British standard of living, 1750-1850', Econ. Hist. Rev., 1966, 2nd series, 19: 581-589. B. R. Mitchell and Phyllis Deane, Abstract of British historical statistics, Cambridge University Press, 1962. E. W. Gilboy, 'The cost of living and real wages in eighteenth-century England', in Arthur J. Taylor (editor) The standard of living in Britain in the Industrial Revolution, London, Methuen, 1975, ch. 1.
} 


\section{Provincial medical practice in eighteenth-century England}

they were. The third possibility is a general rise in medical fees between the early years of the eighteenth century and the time when William Pulsford started in practice. There is some evidence for such a change but uncertainty about the time when it occurred. But there is support for the more general proposition that the fees charged and incomes earned by provincial medical practitioners were substantially higher in the second half of the eighteenth century than in the first. For example, there is a marked difference between two bills submitted by Somerset practitioners in 1737 and 1779 respectively. They were bills to two women who suffered similar conditions, both prolonged and both requiring numerous visits, surgical dressings, and medicines. The first, in 1737, amounted to a total of $£ 107 s .4 d$. and visits (about 130) were charged at about $1 s$. each..$^{43}$ The later bill amounted to $£ 443 s .0 d$. and included fifty-two visits at $5 s$. each. ${ }^{44}$ Of course, the differences between these two bills may have reflected no more than differences between the patients' circumstances or between the habits and reputations of the practitioners. But there is other more comprehensive evidence.

An example is provided by a medical practitioner's day-book for the period $1703-10 .{ }^{45}$ The name of the practitioner is unknown, but he practised near Leeds in Yorkshire. The day-book shows a type of practice that corresponds to the stereotype of the country apothecary, dispensing medicines from a shop. Examples of his notes are shown in Table 7. Medicines were dispensed on the basis of uroscopy and symptoms described either by the patient or by relatives or friends. In only about two per cent of cases was the patient visited, and when that occurred the addresses suggest that visits were confined largely to the well-off. Throughout the day-book, the fees, compared to those of surgeon-apothecaries in the second half of the century, were very low. Moreover, this practitioner regularly recorded each 1 January his income for the previous year. Between 1703 and 1710, this ranged from $£ 6819 s .9 d$. to $£ 10518 \mathrm{~s} .5 \mathrm{~d}$. Approximately four-fifths of his income came from the sale of medicines and one-fifth from small-scale farming, mostly the sale of cattle. Another apothecary's notebook for 1667-1715 (provenance uncertain) shows prices similar to the Leeds apothecary and an annual income rising gradually from $£ 143$ p.a. in 1697 to $£ 266$ in $1716 .{ }^{46}$

Confirmation of the increased prosperity of medical practice in the mid-eighteenth century is provided by the anonymous author of $\boldsymbol{A}$ general description of all trades (1747), where the trade of the apothecary is described as a "very genteel business and has been in great vogue of late years...". Some apothecaries "... practise Surgery, Man-Midwifery and many times officiate as Physicians, especially in the Country, and often become Men of Large Practice and eminent in their way. ..". ${ }^{47}$ To what extent is this increased prosperity confirmed by an examination of medical

\footnotetext{
${ }^{43}$ Somerset County Record Office, Taunton (Ref. DD.L.2.Misc/4 Box 154).

${ }^{44}$ Ibid. (Ref. DD/DP. 23. 0B4).

${ }^{45}$ Medical practitioner's day-book, 1703-10. The library of the Royal College of General Practitioners, London.

${ }^{46}$ Catalogued as: Personal memoranda and notes of accounts for physic and treatment of patients 1667-1715, probably compiled by John Chaplin of Wareham probably the son of Rev. Thomas Chaplin. Dorset County Record Office, Dorchester (Ref: PH 1).

${ }^{47}$ A general description of all trades, London, 1747.
} 
TABLE 7. EXAMPLES OF ENTRIES TAKEN FROM THE DAY-BOOK OF A MEDICAL PRACTITIONER NEAR LEEDS, YORKSHIRE, BETWEEN 1703 AND 1710.

"It. Mrs Hawksworth, pain back and body", ointment prescribed

"It: urin: John Booth, Rawden, foul rotten water, pain in breast, cough", medicines dispensed

"It: urin: Jeremy Garth son Bolton, high colour, aguish fever, pain in head", medicines dispensed

"It: urin: James Pearson wife Denholm, lingering slow fever, pain in head", medicines dispensed

"It: urin: Richard Brook son Cleckheaton, age 24, pale colour, stomach clog'd, pain in breast", medicines dispensed

"It: to John Clapham, Ottley, cough consumptive like, brest stopt", medicines dispensed

"It: urin: Young woman age 17 years, pale colour, epileptick fits feared", elixir prescribed

"It: visit to Mrs Langley Priestly Greekn, Rheumatism, pain in back and body", medicines dispensed

"It: visit to John Walker Ganthrop Hall, cough, consumption feared", medicine dispensed

"It: visit to Mr Stead son, Baylock, surfet, cough, consumptive", medicine dispensed

"It: to Daniel Hanniway, Sorwoodhouse, cough, stopping in brest, vomiting of bile, water", medicine dispensed

"It: visit to his son there age 22 years, cough, surfet, consumptive like", medicines dispensed

M. Received for Medicines contained in the former Note Book \& in this from January 1 st $1702 / 3$ to January 1 st $1703 / 4, £ 56.18 .1 \&$ from other goods $£ 13.14 .8 d$ being in all the sum of-

f s. d.

$\begin{array}{lll}0 & 0 & 4\end{array}$

$\begin{array}{lll}0 & 2 & 10\end{array}$

$\begin{array}{lll}0 & 0 & 6\end{array}$

$\begin{array}{lll}0 & 1 & 0\end{array}$

$\begin{array}{lll}0 & 0 & 4\end{array}$

$\begin{array}{lll}0 & 2 & 6\end{array}$

$\begin{array}{lll}0 & 0 & 4\end{array}$

$\begin{array}{lll}0 & 15 & 4\end{array}$

$\begin{array}{lll}0 & 7 & 0\end{array}$

$\begin{array}{lll}0 & 5 & 0\end{array}$

$\begin{array}{lll}0 & 0 & 6\end{array}$

$\begin{array}{lll}0 & 2 & 0\end{array}$

$\begin{array}{lll}70 & 12 & 9\end{array}$

Source: Medical notebook donated to the Royal College of General Practitioners by Dr Jameson. Library of the College.

records of this period? The most frequent records of medical practice are practitioners' bills. Some are private bills; many are bills from parish surgeons to overseers of the poor. A number of these were examined and certain commonly recurring items were selected for comparison-the cost of two common types of medicine (mixtures and draughts) and the cost of journeys or visits. These, with the average cost of all the medicines prescribed, were abstracted from the bills and a selection of the results of this exercise is shown in Table 8.

TABLE 8. EXAMPLES OF FEES CHARGED BY MEDICAL PRACTITIONERS IN THE EIGHTEENTH AND EARLY NINETEENTH CENTURY IN TERMS OF AN AVERAGE FEE FOR MEDICINES, THE FEE FOR MIXTURES, DRAUGHTS AND FOR JOURNEYS OR VISITS, TAKEN FROM BILLS TO PRIVATE PATIENTS AND TO OVERSEERS OF THE POOR IN VARIOUS PARTS OF ENGLAND.

$\begin{array}{ll}\begin{array}{l}\text { Reference } \\ \text { to } \\ \text { source }\end{array} & \text { Date } \\ \text { Private } & \text { medical bills } \\ 1 . & 1697 \\ 2 . & 1703-10 \\ 3 . & 1712 \\ 4 . & 1735 \\ 5 . & 1737\end{array}$

Average Fee

fee for for

Source

Mrs Tudway, Somersetshire 1s. Od.

1s. Od.

Fee

medicines mixtures

for

draughts

Fee

for

journeys

Charges of a Yorkshire practitioner near Leeds

Mrs Tudway, Somerset

Alexander Popham

4s. $-1 s .0 d$

Mrs Luttrell, Somerset 1s. $4 d$.

$8 d$.

$9 d$. 1s. $6 d$.

2s. Od.

1s. $6 d$.

1s. $0 d$. 


\section{Provincial medical practice in eighteenth-century England}

\begin{tabular}{|c|c|c|c|c|c|}
\hline $\begin{array}{l}\text { Reference } \\
\text { to } \\
\text { source }\end{array}$ & Date & Source & $\begin{array}{l}\text { Average } \\
\text { fee for } \\
\text { medicines }\end{array}$ & $\begin{array}{l}\text { Fee } \\
\text { for } \\
\text { mixtures }\end{array}$ & $\begin{array}{l}\text { Fee } \\
\text { for } \\
\text { draughts }\end{array}$ \\
\hline
\end{tabular}

Private medical bills (cont.)

\begin{tabular}{|c|c|c|c|c|c|c|}
\hline $\begin{array}{l}6 . \\
7 .\end{array}$ & $\begin{array}{l}1745-48 \\
1742\end{array}$ & $\begin{array}{l}\text { Mr Dickinson, Somerset } \\
\text { Thomas Carew, Somerset }\end{array}$ & $\begin{array}{l}1 s .0 d . \\
1 s .0 d .\end{array}$ & 1s. Od. & 1s. Od. & 10s. $6 d$. \\
\hline 8. & 1754 & Thomas Carew, Somerset & $2 s .9 d$. & $1 s .6 d$. & $2 s .6 d$. & \\
\hline 9. & 1759 & Mr Talbot, Bedfordshire & 2s. $0 d$. & & 1s. Od. & $2 s .6 d$. \\
\hline 10. & $1766-71$ & $\begin{array}{l}\text { Charges of Mr Misters, } \\
\text { surgeon at Shipston-on- } \\
\text { Stour, Warwickshire }\end{array}$ & 2s. $1 d$. & & & \\
\hline 11. & $1768-73$ & $\begin{array}{l}\text { Charges of William Elmhirs } \\
\text { of Yorkshire }\end{array}$ & $2 s .0 d$. & & 1s. $9 d$. & $2 s .-7 s$. \\
\hline 12. & $1772-79$ & Mrs Sandford, Somerset & 2s. $6 d$. & & & 5s. $0 d$. \\
\hline 13. & 1782 & Mrs Blackall, Somerset & 2s. $0 d$. & $1 s .6 d$. & 2s. $6 d$. & \\
\hline 14. & $1788-1800$ & William Carr of Leeds & 1s. $6 d .-2 s$. & 1s. $0 d$. & 2s. $6 d$. & \\
\hline 15. & 1801 & Mr Gibbs, Somerset & & 1s. Od. & 2s. $3 d$. & \\
\hline 16. & 1818 & $\begin{array}{l}\text { Fees charged by Mr Tuson, } \\
\text { apothecary, Northants }\end{array}$ & 3s. $2 d$. & 1s. $6 d$. & 3s. $6 d$. & \\
\hline
\end{tabular}

Bill submitted by parish surgeons to overseers of the poor

\begin{tabular}{|c|c|c|c|c|c|c|}
\hline 17. & 1725 & $\begin{array}{l}\text { Parish of Bridewater, } \\
\text { Somerset }\end{array}$ & $9 d$. & $8 d$. & 1s. $6 d$. & 1s. Od. \\
\hline 18. & 1746 & $\begin{array}{l}\text { Parish of Bishop's Hull, } \\
\text { Somerset }\end{array}$ & $7 d$. & $6 d$. & $8 d$. & \\
\hline 19. & $1767-70$ & $\begin{array}{l}\text { Parish of Broomfield, } \\
\text { Somerset }\end{array}$ & & & & 5s. Od. \\
\hline $\begin{array}{l}20 . \\
21 .\end{array}$ & $\begin{array}{l}1768 \\
1784\end{array}$ & $\begin{array}{l}\text { Parish of Hutton, Somerset } \\
\text { Parish of Brington, }\end{array}$ & & & 2s. $0 d$. & 2s. $6 d$. \\
\hline 22. & 1786 & $\begin{array}{l}\text { Northants } \\
\text { Parish of Badgworth, } \\
\text { Somerset }\end{array}$ & $\begin{array}{l}1 s .9 d . \\
1 s .9 d .\end{array}$ & $8 d$ & 2s. Od. & $\begin{array}{l}2 s .6 d . \\
2 s .6 d .\end{array}$ \\
\hline $\begin{array}{l}23 . \\
24 .\end{array}$ & $\begin{array}{l}1786 \\
1792-93\end{array}$ & $\begin{array}{l}\text { Parish of Babcary, Somerset } \\
\text { Parish of Charlton } \\
\text { Mackerell, Somerset }\end{array}$ & $2 s .3 d$. & & 1s. $6 d$. & 5s. Od. \\
\hline $\begin{array}{l}25 . \\
26 .\end{array}$ & $\begin{array}{l}1799 \\
1819\end{array}$ & $\begin{array}{l}\text { Parish of Caddington, Herts } \\
\text { Parish of Easton-in- } \\
\text { Gordano, Somerset }\end{array}$ & $\begin{array}{l}2 s .3 d . \\
2 s .6 d .\end{array}$ & 2s. $6 d$. & 1s. $0 d$. & 2s. $6 d$. \\
\hline
\end{tabular}

Sources:

Abbreviations: SCRO $=$ Somerset County Record Office

NCRO $=$ Northamptonshire County Record Office

BCRO $=$ Bedfordshire County Record Office

Private patients' bills

1. SCRO DD/TB Box 16

2. Notebook of a Leeds practitioner

3. SCRO DD/TD Box 16

4. SCRO DD/TB BOX 13.8

5. SCRO DD.L.2 Misc/4 Bx 154

6. SCRO DD/DN 206

7. SCRO DD/TB Box 10

8. SCRO DD/TB Box 14. 20

9. BRCO CRT $110 / 27$

10. Wellcome MS 3584, Wellcome Institute Library

11. Sheffield Public Library FH/13 63398
Overseers' bills

17. SCRO DB. bw. 2323

18. SCRO D/P/ b. hl. $18 / 2 / 11$

19. SCRO D.P.broo. $13 / 2 / 3$

20. SCRO D.P.Hut. $13 / 2 / 1-3$

21. NCRO 49/P. 151

22. SCRO D/P/Badg. 13/2/4,5

23. SCRO D/P Bab. 13/2/1

24. SCRO D.P. Cha. Ma. 13/2/1,2

25. BCRO DDP $35 / 12 / 2$

26. SCRO D.P. E.in.G. 13/2/2 


\section{Irvine Loudon}

Table 8 (cont.)

Private patients' bills

12. SCRO DD/DP.23.OB.4

13. SCRO DD/TB Box $15 / 11,12$

14. Wellcome MS (uncatalogued) Wellcome Institute Library

15. SCRO D/P/Chedz 13/10/4. s341

16. NCRO CA 242

Other examples are provided by overseers' bills for other forms of medical and surgical care. Overseers were required to be sternly economical with parish money; they could, and sometimes did, refuse to pay charges which seemed excessive. Yet, with few exceptions, they did not object to fees charged by parish surgeons equivalent to the charges made to private patients. For example, the overseers of the parish of South Cadbury in 1775 paid the parish surgeon 15s.6d. for one journey and "setting a lad's collar bone"-the simplest of all fractures to deal with. ${ }^{48}$ In $1771, \mathrm{Mr}$ Bryant was paid by the overseers of the parish of Broomfield, $£ 819 \mathrm{~s} .0 \mathrm{~d}$. for "laying open and curing an Imposthumation", and in 1770 they paid three guineas for the reduction of a fractured thigh. ${ }^{49}$ In 1746 , however, the fee paid by the overseers of the parish of Bishop's Hull in Somerset for opening and curing a large abscess in the head-which required a series of visits-was only $10 s .6 d .^{50}$ The contracts when the surgeon was paid by salary often show a similar difference. In Bedfordshire in 1729, John Sharpe, apothecary, contracted with the overseers of the poor at Eaton Socon to supply all care to the poor (including medicines) for $£ 5$ for a period of fifteen months. In contrast, Walter Borlase, parish surgeon in 1790 to Ampthill, was paid eleven guineas a year for a similar contract. ${ }^{51}$ The parish surgeons of Stour (Stower) Provost in Dorset were paid a retaining salary for all treatment except midwifery, smallpox, and broken bones. In 1786 the salary was five guineas p.a.; in 1787, $£ 8$; and by 1803 it was twelve guineas. As the population of the parish in 1801 was only 604 , these salaries must have been easily earned. ${ }^{52}$ This evidence suggests that the fees charged by provincial practitioners increased around 1740-50 and then, from 1750 until the early nineteenth century, remained level, with the exception of fees to parish surgeons which often rose sharply in the early nineteenth century. The prosperity of practitioners depended not just on the fees they could charge, but also on the number of patients per practitioner and the amount of medicine and other forms of care those patients could be persuaded to accept. Rough estimates of doctor/population ratios can occasionally be made in the eighteenth century, but accurate estimates are generally impossible before the census of 1841 . As for the quantities of medicine provided, these, in the eighteenth century, were often astonishing. The "Golden Age of Physic" was based on the sale of vast quantities of medicine, much of it made up in small individual bottles or packages, each charged individually to maximize profits.

\footnotetext{
${ }^{48}$ Somerset County Record Office (Ref: D. P. Cad. S.13/2/4).

${ }^{49}$ Ibid. (Ref: D.P. Broo. 13/2/3).

${ }^{50}$ Ibid. (Ref: b/p/b.h1. 13/2/11).

${ }^{51}$ Bedfordshire County Record Office (Ref: DDP 5/12/4 \& P/30/8/1).

${ }^{52}$ Dorset County Record Office (Ref: P354/OV4,5).
} 


\section{Provincial medical practice in eighteenth-century England}

For example, at the end of 1754, the medical attendant to the Carews of Crowcombe Court, Somerset, presented his bill for the year. ${ }^{53}$ This one family had been supplied in $\mathbf{1 7 5 4}$ with medicine, delivered daily including Sundays except for a few gaps here and there, totalling 687 items plus seven bleedings and two blisters. The bill (twenty-three closely written foolscap pages) came to $£ 1545 \mathrm{~s} .7 \frac{1}{2} \mathrm{~d}$., of which $£ 50$ was carried forward from a previous unpaid bill. By comparison, the same family in 1737 paid $£ 416 s .6 d$. for about 450 items of medicine.$^{54}$ Other bills for medicine supplied to private patients in Somerset confirm the large quantities provided.

Richard Smith junior in Bristol furnished vivid evidence of the profits to be made from the dispensing of medicine until the appearance of the dispensing chemists brought the golden age to an abrupt halt. Smith, as a young man, "had a patient bequeathed to me by $\mathrm{Mr}$ Alland who frequently took day and night (for if he was awake he took a draught) six or seven bottles-my apprentice regularly made up and ready two or three packets",, 5 and his aunt took some mysterious pills on certain days "her regular banyon or blackwood days" and paid her apothecary $£ 30$ to $£ 40$ every Christmas. ${ }^{56}$ Certain medicines containing musk or oil of cinnamon were used for "grandees", and these were charged at 10 s.6 ., of which at least 10 s. was profit. A family called the Greenlys at Clifton "could not move without a regular supply of physic - they took with them to Weymouth 200 'tonic draughts' and one thousand pills of various descriptions-as there were no pill machines in those days Lassall [the apothecary's apprentice] told Smith he was 'sick to death with the rolling of them'." The upper and middle classes, at least, were great medicine-takers in the eighteenth century, not only for illness, real or imagined, but for the prevention of disease or the general belief that medicines improved their health. In addition, "there were abundance of people who, every spring and fall, lost blood and were disciplined for a fortnight or three weeks" ${ }^{58}$ Others required an issue to be made and kept open (sometimes for months or even years), imagining themselves ill if it was not kept discharging. ${ }^{59}$ The sale of medicine, however, held pride of place, outstripping the surgeon's bleeding, blisters, and issues.

In this respect, the purchase of medicines and medical care was a part of the commercial boom in eighteenth-century England. Recently, a number of historians have drawn attention to the birth of the consumer society and the "consumer revolution" of the third quarter of the eighteenth century. ${ }^{60}$ The impression of a rise in prosperity of medical practitioners dating from 1740-50 coincides with evidence of a rapidly expanding market economy from the mid-century. Farmers and

\footnotetext{
${ }^{53}$ Somerset County Record Office, Bill for Mr Bernard Baine to Thos. Carew Esq. 1754 (Ref. DD/TB Box 14/20).

${ }^{54}$ Ibid. (Ref. DD/TB Box 13/8).

${ }^{55}$ Bristol Infirmary biographical memoirs, op. cit., note 20 above, vol. 2, p. 153.

${ }^{\text {se Ibid., p. } 154 .}$

${ }^{57}$ Ibid., pp. 155 and 156.

${ }^{58}$ Ibid., p. 154.

${ }^{59} \mathrm{An}$ issue was an incision through the skin (usually on the upper arm, back, or thigh) kept open and discharging by the insertion into the wound of a variety of small objects. It was supposed to act as an exit or drain for acrid humours in the blood. There is a good discussion of issues in Samuel Cooper, Dictionary of practical surgery, 7 th ed., London, 1838.

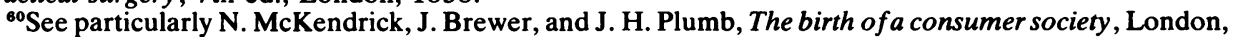
Europa 1982; and Porter, op. cit., note 27 above, ch. 5: 'Getting and spending'.
} 


\section{Irvine Loudon}

manufacturers of the kind found in Wells thrived as never before, and medical practitioners cashed in on this market. From the point of view of the costs of starting in business and basic costs of materials, there were few occupations so profitable as that of the surgeon-apothecary. As Campbell remarked in 1747 of the apothecary: "There is no Branch of Business, in which a Man requires less Money to set him up than this very profitable trade. ... His profits are unconceivable. ..."

Adam Smith's well-known defence of the apothecary in 1776 must have gladdened the hearts of medical practitioners at a time when they were beginning to be criticized for their fees: "The skill of an apothecary is a much nicer and more delicate matter than that of any artificer whatsoever. ..", and though he should sell his drugs at a profit of a thousand per cent, ". . . this may frequently be no more than the reasonable wages of his labour charged, in the only way he can charge them, upon the price of his drugs. The greater part of the apparent profit is wages disguised in the garb of profit." ${ }^{\text {1 } 1}$ Adam Smith suggested that the apothecary in a market town could earn an income of $£ 400-£ 500$ a year, which is in line with the estimated income of the Pulsfords in the 1750s.

Nearly all the examples in this paper have been drawn from the South of England. Income levels may have been lower in the North. William Elmhirst in Yorkshire, for example, is estimated to have earned about $£ 250$ a year from medical practice; ${ }^{\mathbf{6 2}}$ and it should be mentioned in passing that the fees earned by country surgeons in Scotland were very much lower than those in England. In fact, the poverty of country practice in Scotland was proverbial in the nineteenth century as well as the eighteenth. ${ }^{63}$ In England, however, the income of the country practitioner often compared favourably with that of other trades and professions. For example, Joseph Massie's estimates of income for 1759-60 were $£ 100$ p.a. for the superior clergy, and $£ 50$ p.a. for the inferior; $£ 100$ p.a. for persons professing the law; and $£ 150$ for the richest farmers. ${ }^{64}$ Possibly, the estimates for law and the church are on the low side. The legal profession became increasingly prosperous through the growth of nonlitigious business, and Holmes suggests $£ 100-£ 200$ as the income of minor clergy and $£ 250$ at least for the middle ranks. ${ }^{65}$

The successful medical practitioner could look for extra sources outside the fees for private practice. In particular, medical care provided by the parish under the

\footnotetext{
'1 Adam Smith, Wealth of nations, London, 1776.

${ }^{62}$ The Elmhirst ledger, Sheffield Public Library, local collection, (accession no: FH/13 63398). See also, E. M. Sigsworth and P. Swan, 'An eighteenth-century surgeon and apothecary: William Elmhirst (172173)', Med. Hist., 1982, 26: 191-198.

${ }^{63}$ The account-book of James Steedman of Kinross dating from 1758 (the library of the Wellcome Institute for the History of Medicine, London, MS 4702) demonstrates the low fees charged; and another fine example can be found in the bill to a Writer in Lanark in 1759 in John Glaister, Dr Smellie and his contemporaries, Glasgow, James Maclehose, 1894, pp. 16-17. See also, Sir Walter Scott, The surgeon's daughter, new ed., London, George Routledge, 1831 (first published in 1827): "There is no creature in Scotland that works harder and is more poorly requited than the country doctor, unless perhaps, it be his horse." The hero of this novel, the surgeon Gideon Grey, was said to travel 5,000 miles a year on horseback and earn less than $£ 200$ p.a. Gideon Grey was based on a true Scottish practitioner, Dr Clarkson of Selkirk, and the detail is accurate.

${ }^{64}$ Peter Mathias, 'The social structure in the eighteenth century: a calculation by Joseph Massie', Econ. Hist. Rev., 1957-58, 2nd series, 10(1): 30-45.

${ }^{65}$ Holmes, op. cit., note 2 above, pp. 93-96.
} 


\section{Provincial medical practice in eighteenth-century England}

"old" poor law provided a reasonable standard of care for the poor and often a substantial income to the practitioners, particularly when the records show clearly that many practitioners held appointments at several parishes, as, indeed the Pulsfords did ${ }^{68}$ The poor law records of payment to practitioners in various counties tend to support the conclusions of Lane, whose extensive work on poor law surgeons in Warwickshire in the eighteenth century suggested that "... in the half century before $1800 \ldots$ medical attention for the regular and occasional poor ... was not appreciably worse than other villagers enjoyed" . ${ }^{87}$ Indeed, it may have been better. The lowest fee charged by William Pulsford was $5 s$. In the South and West of England in 1768, Arthur Young found that the pay per week of a day labourer varied from $4 s .6 d$. to $10 s$. (briefly, in the harvest) and was, on average, $5 s$. a week. ${ }^{68}$ It would have been difficult or impossible for a labourer in Wells to have employed Pulsford's services, even for the slightest of illnesses. A correspondent wrote in 1787: "The apothecaries in the country charge so high for their attendance and medicines that a poor distressed hardworking man (if he is a few weeks in illness) dreads the consequences of employing them, as if he survives the illness he knows it will be an additional drawback in his labour (for perhaps several years) to get clear of the apothecary." the second half of the eighteenth century was spectacular. In Taunton, for example, the first was established in 1751 ; by 1796 , there were $114 .^{70}$ These societies not only helped the poor in sickness, they provided another source of income for medical practitioners. There are a few scattered references in the Pulsford ledger to payments by "the clubb". But later, in the 1790s, a practitioner from Towcester, a Mr Sabin, derived a substantial income from club practice, particularly the "Bear Club". ${ }^{11}$

So far in this paper, obstetrics has scarcely been mentioned. Although for reasons of space, clinical practice cannot be discussed, some mention should be made of the economic aspects of the practice of man-midwifery. Some practitioners undertook obstetrics because there was no one else in their area to do so; others used it as a means of becoming established, and gave it up as soon as they could; and some persisted with it from the enjoyment of exercising an acquired skill. ${ }^{72}$ Very few did it for profit. "I know of no surgeon", wrote Richard Smith, "who would not willingly have given up attending midwifery cases provided he could retain the family in other

\footnotetext{
${ }^{8}$ In Bedfordshire, for example, Mr MacGrath of Biggleswade was, in 1811, the parish surgeon to seven parishes. The smallest with a population of eighty-eight paid him $f 44 \mathrm{~s} .0 \mathrm{~d}$. a year; the largest (which he shared with another surgeon) had a population of 1,895 and MacGrath's share was $£ 2210$ s.0d. a year. For attending the poor of all seven parishes (total population 3,429) he earned, in 1811, £106 5 s.0d. Bedfordshire County Record Office, Bedford. The Whitbread Correspondence (Ref. W/773).

${ }^{67}$ Joan Lane, 'The provincial practitioner and his services to the poor, 1750-1800', Bull. Soc. soc. Hist. Med., 1981, 28: 10-14.

${ }^{68}$ Arthur Young, $A$ six weeks tour through the southern counties of England and Wales, London, 1768.

${ }^{69}$ Correspondence of the 2nd Earl of Hardwicke. Letter from Joseph Pawsey (1787). British Library, Add. MS 35,694. (Transcript in Bedford County Record Office, ref: CRT 100/27/3 (II), p. 132.)

${ }^{70}$ Margaret Fuller, West country friendly societies, University of Reading, Museum of English Rural Life, 1964.

${ }^{71}$ Northampton County Record Office, Mr Sabin, prescription book 1797-98 (Ref. YZ 1770).

${ }^{72}$ For example, John Padmore Noble, surgeon to Bristol Infirmary from 1777-1812: "Undoubtedly his forte was man-midwifery and, feeling himself so completely at home in this branch might give him a pleasure which balanced in his mind its privations and inconveniences." Bristol Infirmary biographical memoirs, op. cit., note 20 above, vol. 2 , p. 840 .
} 


\section{Irvine Loudon}

respects.... I do not speak of the Metropolis...."73 Smith was right; outside London (an important exception) obstetrics was poorly paid in terms of the time involved and the enormous mental and physical strain of prolonged and anxious attendance where the outcome was so uncertain. ${ }^{74}$ The unprofitable nature of man-midwifery is shown by the records of Danvers Ward, a Bristol surgeon who, failing in several attempts to become elected to the Infirmary, cultivated faute de mieux a large obstetric practice. He made the memorable claim of having in one year "... put to bed two hundred and forty six women, of which number twenty were confined in the space of one week". ${ }^{75} \mathrm{He}$ may have boasted, for recently I found his accounts for $1787 .{ }^{76}$ In that year, he delivered 121 women. No payment was recorded for fifteen, half a guinea for seventy-seven, one guinea for fifteen, two guineas for twelve, and three guineas for two. In the same year, he recorded 161 consultations for other conditions. These were not usually defined, but they included fractures, dislocations, bleedings, and tooth extractions. As a whole, the other consultations would have been much less arduous than obstetrics; yet the average fee for midwifery cases was 14.4 shillings, and for the non-obstetric, 14.3 shillings, ${ }^{77}$ although as a well-known man-midwife in Bristol, Ward probably commanded high fees for his services. At all events, for the time and effort involved, medicine and surgery were much more profitable than midwifery, provided the practitioner could be fully employed in them.

Sometimes, medicine in the eighteenth century is described as an occupation in which the élite of physicians and surgeons could make a fortune, while the rank and file struggled desperately against a distrustful public and an army of successful quacks. The evidence here suggests, on the contrary, that there was an extraordinarily favourable market to be exploited by surgeon-apothecaries imbued with a lively spirit of hard commercialism during the second half of the eighteenth century. Subsequent changes are beyond the period of this paper, but evidence presented previously suggests that there was a sharp decline in the income of the successors to the apothecaries and surgeon-apothecaries-the general practitioners-during the first half of the nineteenth century; and that this decline was due mainly to three factors, the increased cost of medical education, competition from dispensing druggists, and the over-production of medical practitioners following the Apothecaries' Act of 1815. ${ }^{78}$

Thus, there is no support for the common view that the prosperity of the rank-andfile practitioners of medicine steadily increased from the eighteenth into the

\footnotetext{
${ }^{73}$ Ibid., vol. 2, p. 157.

${ }^{74}$ The memoirs of Richard Paxton who practised in Maldon, Essex, c.1750-90, provide vivid examples of the grim reality of man-midwifery as practised in the country in the eighteenth century. Library of the Wellcome Institute, London, MS 3820.

${ }^{75}$ Bristol Infirmary biographical memoirs, op. cit., note 20 above, vol. 4, pp. 48-50.

${ }^{76}$ The cash-book of Danvers Ward of Bristol, 1786-7. Gloucester County Record Office (Ref: D 1928, A3).

${ }^{77}$ Dr John McCulloch of Liverpool, who delivered, between 1797 and 1810, 2900 women, charged closely similar fees to those of Danvers Ward. The average fee recorded was 15.3 shillings. I am grateful to Mr Paul Laxton of the Department of Geography, Liverpool University, for providing this information and allowing me to publish these results of his research.

${ }^{78}$ Irvine Loudon, 'A doctor's cash-book: the economy of general practice in the 1830s', Med. Hist., 1983, 27: 249-268.
} 


\section{Provincial medical practice in eighteenth-century England}

nineteenth century together with the improved status and education of the general practitioner. The opposite seems to be the case. If the practitioners of the second half of the eighteenth century were better off than their nineteenth-century successors, what was their standing in society? What, in particular, was the position of the Pulsford family in Wells?

\section{VII}

Benjamin Pulsford was a man of considerable property. He inherited a landed estate from his uncle, Christopher Lucas (see Part I), bought property in both the Inand the Out-parish of Wells and the parish of Croscombe, and purchased from Lord Waldegrave land in Woodford. He also owned a fourth share of a lead mine. The property in his house, which he divided amongst his sons in his will, included furniture, pictures, "useful" and "ornamental" china, books on "physick and surgery", "the skeleton in my surgery", pistols and at least three sporting guns, one of them silver-mounted. He also bequeathed his horses to his sons. Three close friends are remembered in his will, one being a partner in the lead mine. Two are simply described as "Gentlemen" and the third was the Reverend John Prowse of Camerton. ${ }^{79}$

Although little is known of the social standing of the Pulsfords, one is left with the impression that they were literate but not learned men, more interested in field sports and farming than religion, philosophy, or the arts. They were businessmen, able and willing to command high fees for their skills, and as a consequence they were prosperous.

Wells in the eighteenth century was predominantly a market town, dependent on agriculture and the clothing industry, particularly stocking-making. The uplands of the Mendips were unenclosed until the 1770 s, but the lowlands were richly cultivated. In 1801 , the population of Wells was 4,505 . It is generally supposed that the population had altered little and had been in the region of 4,000 to 5,000 at least for a hundred years previously. ${ }^{80}$ The surrounding villages visited by the Pulsfords cannot have contributed an extra population of more than, at most, another 5,0007,500. Yet, in 1780, this population supported seven surgeon-apothecaries (including two Pulsfords-Benjamin and Lucas) and at least one physician ${ }^{\mathbf{8}}$ Even if some of these practitioners spent much of their time in additional occupations such as farming there must have been a thriving market for orthodox medical care. And there is no reason to believe that in this respect Wells was exceptional. Taking into account all the social and economic data discussed above, can the practice of the Pulsfords and their contemporaries be described as a trade or craft, or should it be seen as a clear example of a profession, albeit in the early stages of development?

The trade versus profession debate is a recurrent and popular preoccupation of social historians. ${ }^{82}$ Few would dissent from the view that there was not, by any

\footnotetext{
${ }^{79}$ Somerset County Record Office (Ref. DD/TD. 29/43; DD/FS Box 42, c 648; DD/SAS SE 23, c 795).

${ }^{80}$ Rev. John Collinson, The history of Somersetshire, vol. 3, London, 1791. Phelps, op. cit., note 12 above. Robin Atthill (editor), Mendip, a new study, Newton Abbott and London, David \& Charles, 1976. Victoria County History, op. cit., note 42 above.

${ }^{81}$ Samuel Foart Simmons, Medical Register, 1780.

${ }^{82}$ A. M. Carr-Saunders and P. A. Wilson, The professions, London, Frank Cass, 1964 (originally
} 


\section{Irvine Loudon}

important criteria, a unified medical profession before the nineteenth century. Likewise, most would agree that physicians, collectively, displayed some at least of the accepted features of a profession. The difficulty arises in attempting to assign an agreed status - an acceptable labe- to the country surgeons and apothecaries, without falling back on a process of backwards extrapolation from their nineteenthcentury successors. Freidson, for example, singled out autonomy as the key feature of the professions in the sense of the right of an occupation to control its own work. Moreover, that autonomy is seen as a privilege conferred by society. In theory, physicians in the eighteenth century possessed such privileges and powers, at least at the level of their London College, and attempted, however weakly, to enforce their monopoly through the legal powers they possessed. But the lower ranks of medical men were subject to no formal education, no examination, and no licensing. They were not, in the sense intended by Freidson, an autonomous group, granted (by society) the power and right to control their own affairs. The Society of Apothecaries, the Company of Barber-Surgeons, and even more its successor after 1745 the Company of Surgeons, might have been expected to be the bodies through which autonomy could be exerted. But, to the provincial practitioners, they were distant corporations in London to which they owed no loyalty and which had no interest in the welfare, education, or standards of practice of the provincial practitioner.

Apart from autonomy, the criteria by which an occupation may be granted the status of a profession include public recognition, a sense of service, an ethical code enforced by the threat of expulsion from the profession, the setting and maintaining of standards of education and practice, a sense of corporate identity and with this what is called "professional pride". To some, professionalization is no more than a conspiracy to establish a monopoly, cloaked in the disguise of altruistic concern for the welfare of patients or clients. But to many historians involved in the trade $v$. profession debates, the most attractive argument in the long run seems to be that a profession is neither more nor less than a full-time occupation of high status. The attractiveness of this argument is its simplicity. But in reality, it only shifts the problem of definition from the word "profession" to the words "of high status". In the end, this may be merely a circular argument: that an occupation has a high status because it is, or looks like, one of the professions. Whichever of these criteria for the definition of a profession is chosen, none seems to apply decisively to the provincial surgeon-apothecary as described in this paper. Perhaps in the end we should appeal to the contemporary description of the occupation. How did the surgeonapothecaries of the eighteenth century describe themselves? For it may be argued that the use of the term "profession" by the surgeon-apothecary is prima facie evidence of professional status. However, it is found that they referred to their

\footnotetext{
published 1933). W. J. Reader, Professional men, Weidenfeld \& Nicolson, London, 1966. E. Freidson, Profession of medicine, New York, Harper \& Row, 1970. J. L. Berlant, Profession and monopoly. A study of medicine in the United States and Great Britain, Berkeley, Los Angeles, and London, University of California Press, 1975. Ivan Waddington, 'Competition and monopoly in Britain, the campaign for medical registration in Britain', Amsterdams Sociologisch Tijdschrift, No. 2, October 1979: 288-321.

For a recent and cogent review of the debate, see Margaret Pelling, 'Medical practice in the early modern period: trade or profession?', Bull. Soc. soc. Hist. Med., 1983, 32: 27-30.
} 


\section{Provincial medical practice in eighteenth-century England}

occupation much more often as a trade or a business. Richard Smith junior in his extensive biographical memoirs used the terms "being in a good line of business" or "setting up in business" repeatedly. ${ }^{83}$ Campbell and the author of $A$ general description of all trades in 1747 both distinguish clearly between the professions of Divinity, the Law, and Physic and the business or trade of the surgeon and the apothecary. ${ }^{84}$ Yet a young practitioner who "set up in business" was likely to say he did so in order to "practise his profession". There is no inconsistency here. In the transitional state of medicine during the latter half of the eighteenth century the distinction was uncertain and unimportant. Only in legal documents was there a necessity to be decisive. The attorney who drew up a partnership agreement between two Northampton practitioners in 1780 , neatly hedged his bets when he wrote that the partners agreed "to join together in the said several professions trades or businesses of Surgery Midwifery and pharmacy". ${ }^{85}$ Faced with such evidence, the debate set in the adversarial terms of either a trade or a profession may be inappropriate, for it presupposes a sharp divide where none existed. The alternative is to remain on the fence and say that the lower ranks of the profession came somewhere between the tradesman and the professional gentleman. The navy placed their surgeons in just such a position-neither on the upper nor the lower deck, but midway with the Master and the Purser as warrant officers of wardroom rank, while the junior surgeons lived in the gun-room. It was not until the nineteenth century, after the reforms of 1805 , that their status was raised by the granting of the privilege of a uniform, and the naval surgeon was required to wear a "Captain's undress uniform with a standup collar". The physician was distinguished by gold lace on his sleeves, to emphasize that the gap still existed now that the surgeon could lay claim to the status of an officer and a gentleman. ${ }^{86}$

\section{VIII}

This account of provincial practice in the eighteenth century began with two contrary views. The first, a sort of mild Hogarthian caricature, pictured a generally primitive level of medical practice deserving no more than the description of a trade. The second was the more recent thesis of Holmes, who sees a marked advance of the rank-and-file practitioners towards the status of professional men as something that occurred between 1680 and 1730 . The first view clearly underestimates the level of clinical skills and of prosperity in the eighteenth century. As for the second, the evidence suggests that the changes that Holmes described as occurring before 1730 took place at a later period. The increased prosperity and standing of medical practitioners, and more especially the improvements in medical education, were essentially features of the second half of the eighteenth century, even if there are hints of such changes here and there before 1740. Medical education based on the London hospitals and private courses of lectures had scarcely begun before 1750 and

\footnotetext{
${ }^{83}$ Bristol Infirmary biographical memoirs, op. cit., note 20 above.

${ }^{84}$ See notes 32 and 47 above.

${ }^{85}$ Northampton County Record Office, Partnership agreement-undated (Ref. YZ 6070).

${ }^{86}$ Christopher Lloyd and Jack L. S. Coulter, Medicine and the Navy, vol. 3: 1714-1815, London, E \& S Livingstone, 1961.
} 
only became a thriving industry in the last quarter of the century, continuing into the nineteenth. It then became an over-productive industry leading to bitter competition between the general practitioners of the 1830s, '40s, and '50s. If those men looked back in envy at their predecessors, who can blame them? By comparison, the second half of the eighteenth century must have appeared as a golden period for medical practitioners.

\section{ACKNOWLEDGEMENTS}

This paper is part of a study of the origin of the general practitioner and medical reform 1750-1850. The author is a Wellcome Research Fellow and acknowledges with gratitude the support of the Trust. He would like to thank Margaret Pelling and Jonathan Barry for valuable advice, and the staff of the Somerset County Record Office in Taunton for their help with manuscripts. 